\title{
Shrinkage of Grand Fir Wood and its Variability within the Stem
}

\section{Utezanje drva jele i njezina varijabilnost u stablu}

\author{
Preliminary paper • Prethodno priopćenje \\ Received-prispjelo: 22. 12. 2011. \\ Accepted-prihvaćeno: 16. 5. 2012. \\ UDK: $630 * 812.23 ; 674.032 .11$ \\ doi:10.5552/drind.2012.1140
}

\begin{abstract}
This study presents the results of the experiment focused on assessment of the shrinkage of Grand fir (Abies grandis /Douglas/Lindl.) wood and its variability in relation to the position in the stem. The examined sample trees came from the Černokostelecka Area in the Czech Republic. Tangential shrinkage was $7.1 \%$, radial $3.3 \%$ and volumetric shrinkage $10.5 \%$. The results show evident influence of the horizontal position on the evaluated features. The lowest shrinkage values are attained close to the pith; shrinkage toward the bark shows a rising trend. In terms of vertical position, the distribution of shrinkage in the stem did not show any apparent trend. Although the dependence of shrinkage on density proved to be statistically significant, density explains only a small portion of the shrinkage variability..
\end{abstract}

Key words: Grand fir (Abies grandis /Douglas/Lindl.), shrinkage, density, introduced species, variability

SAŽETAK • U radu se prikazuju rezultati istraživanja usmjerenih na ocjenu utezanja drva jele (Abies grandis ) Douglas/Lindl.) i varijabilnost utezanja s obzirom na mjesto uzorka u stablu. Jelovo drvo na kojemu su provedena istraživanja potječe s područja Černokostelecka u Republici Češkoj. Tangencijalno utezanje drva bilo je 7,1\%, radijalno 3,3\% a volumno 10,5\%. Rezultati pokazuju velik utjecaj horizontalnog položaja uzorka na istraživana obilježja. Najniže vrijednosti utezanja drva izmjerene su na uzorcima koji su blizu srži, a uzorci koji su bliže kori pokazuju rastući trend utezanja. S obzirom na vertikalan položaj uzorka u stablu, nije zabilježen očit trend raspodjele utezanja. Iako se ovisnost utezanja o gustoći pokazala statistički signifikantnom, gustoća opisuje samo manji dio varijabilnosti utezanja jelovine.

\section{Ključne riječi: drvo jele (Abies grandis /Douglas/Lindl.), utezanje, gustoća, vrsta drva, varijabilnost}

\section{INTRODUCTION \\ 1. UVOD}

Central European forest management is characterized by dominant usage of autochthonic forest woody plants. Silver fir (Abies alba /Mill.) has for centuries ranked among the most significant European trees. Due to its favorable growth and technological properties for the forest and wood industry, it was hardly replaceable. In comparison with the initial natural presence in the forest vegetation of the Czech Republic of $19.8 \%$, its current portion is about $1 \%$ (MZE 2010). Beran (2006) states the clear absence of Silver fir in the Czech forests in age groups $40-60$ years. In connection with massive recession of Silver fir from the Central European localities, extensive research was started already in the last century

\footnotetext{
${ }^{1}$ Authors are Ph.D. student, assistant and associated professor at Department of Wood Processing, Faculty of Forestry and Wood Sciences, Czech University of Life Sciences Prague, Prague, Czech Republic.

${ }^{1}$ Autori su doktorant, asistent i izvanredni profesor Odjela za obradu drva na Fakultetu šumarstva i znanosti o drvu Češkog sveučilišta bioloških znanosti, Prag, Republika Češka.
} 
for the purpose of finding a tree, which could substitute the favorable characteristics of Silver fir.

Grand fir (Abies grandis /Douglas/ Lindl.) was selected based on positive references as one of the possible trees because of small site requirements, resistance and above-average volume production (Beran and Šindelář, 1996; Šindelář et al, 2006; Podrázský and Remeš, 2008; Podrázský and Remeš, 2009; Mitze, 2010). The natural habitat of Grand fir is the Northwest coast of North America. The climatic conditions in its natural habitat range from mild maritime to downright continental climate (Foiles et al, 1991; Alden, 1997; Klinka, 2007). Grand fir is considered in the Central European region to be a prospective introduced tree species. The quick and high volume yield coupled with the lower density predetermines this species for efficient industrial application (Hapla, 2006; Vos and Kharazipour, 2010; Hof et al, 2008; Mitze, 2010). In terms of growth and production, Grand fir is being monitored in many experiments and provenance tests. Current research supports its possibilities and growth potential mainly in juvenile years (König, 1995; Podrázský and Remeš 2008; Rau et al. 2008; Hof et al, 2008).

One of the most important physical properties of wood is shrinkage. This is a process in which the water in the cell walls evaporates from the wood resulting in dimensional and volume changes. Shrinkage describes the intensity of these changes in the wood. Wood shrinkage has a substantially anisotropic character (Bosshard, 1974; Požgaj et al, 1997; Niemz, 1993). Shrinkage is most intensive in the transverse directions, mainly in the tangential direction. Knowledge of the shrinkage values is fundamental for quality drying of the wood, hydrothermal treatment, impregnation, assurance of shape consistency and quality processing and working of the wood including surface finishes. Shrinkage of the wood continues to be a wood research subject (Kärki, 2001; Pelz et al, 2003; Riebel, 2007; Kord et al, 2010).

Wood as an organic material of plant origin shows substantial variability of properties (Josza and Middleton, 1994; Hapla and Wellhausen, 2003). The different shrinkage values in relation to the position in the trunk are confirmed by many authors (Ying et al, 1994; Dumail and Castera, 1997; Kärki, 2001; Perstorper et al, 2001; Wang et al, 2008; Yamashita et al, 2009; Kord et al, 2010; Leonardon et al, 2010). Wood density can be considered the key indicator of wood quality. From the density value, it is possible to derive other significant mechanical and physical properties of wood that are also important for practice (Bosshard, 1974; Niemz, 1993; Požgaj et al, 1997; Niemz and Sonderegger, 2003). This dependence can also be found between density and shrinkage.

This is one of the results of the extensive study focused on the assessment of the quality of Grand fir wood in the Czech Republic. The main idea of the experiments was to evaluate the position of Grand fir among the domestic firs, and acquire data for the application of Grand fir wood in the wood processing industry. Last but not least, the assessment was to be made of the possibilities for replacing the domestic fir wood. The objective of this work was to determine the shrinkage of grand fir wood from the Czech Republic and to establish its trunk variability in relation to the vertical and horizontal position. The dependence of shrinkage on density was also evaluated.

\section{MATERIAL AND METHODS 2. MATERIJALI I METODE}

The locality for the collection of Grand fir sample trees was situated close to Kostelec nad Černými lesy village. The territory lies at a distance of $25-50 \mathrm{~km}$ south-east of Prague. The height above sea level of these localities is in the range of $325-430 \mathrm{~m}$. A closer description of the localities is given by Podrázský and Remeš (2009) and Tauchman et al. (2010). A total of six representative Grand fir specimens were taken from

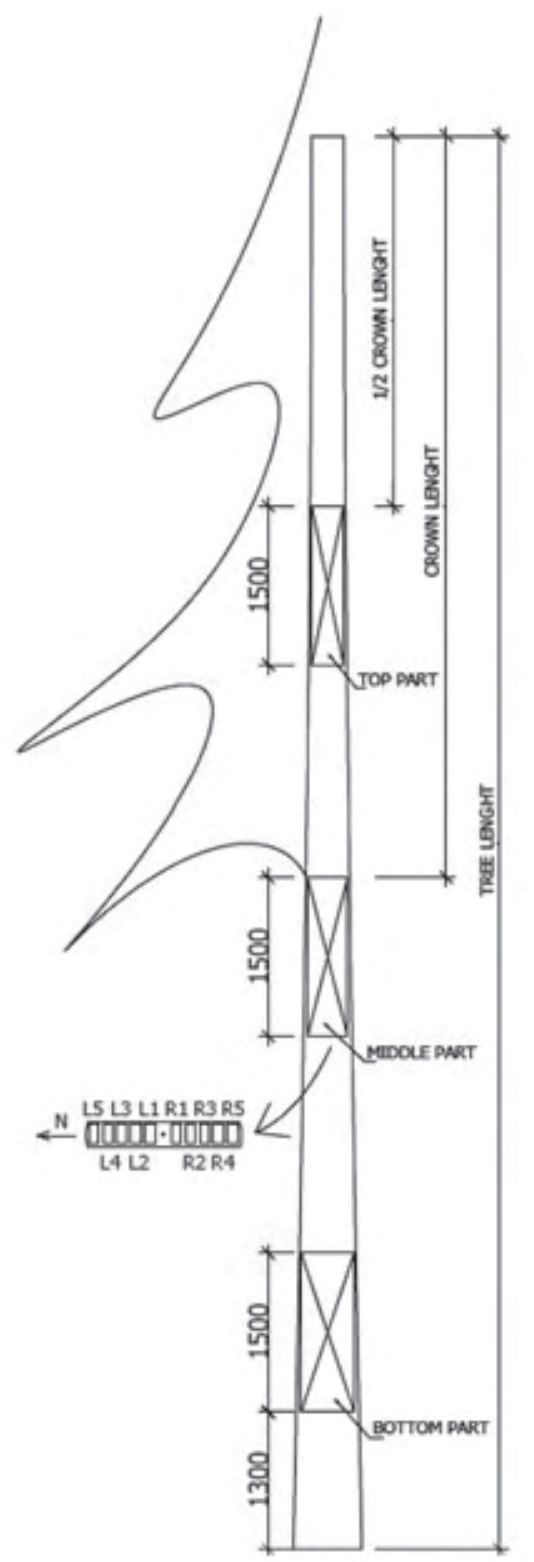

Figure 1 Tree sampling and horizontal position of the plank testing samples

Slika 1. Uzimanje uzorka iz stabla i horizontalan položaj uzorka u odsječku stabla 


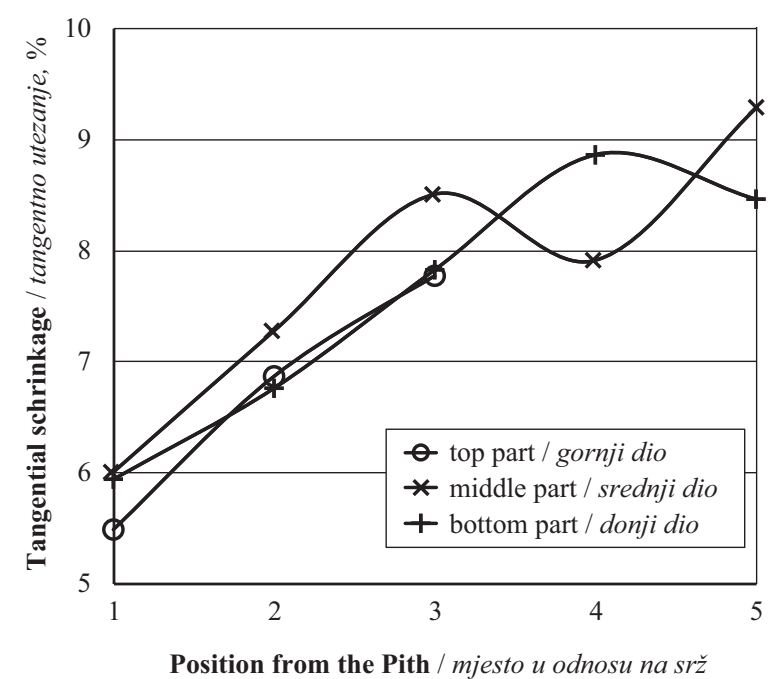

a)

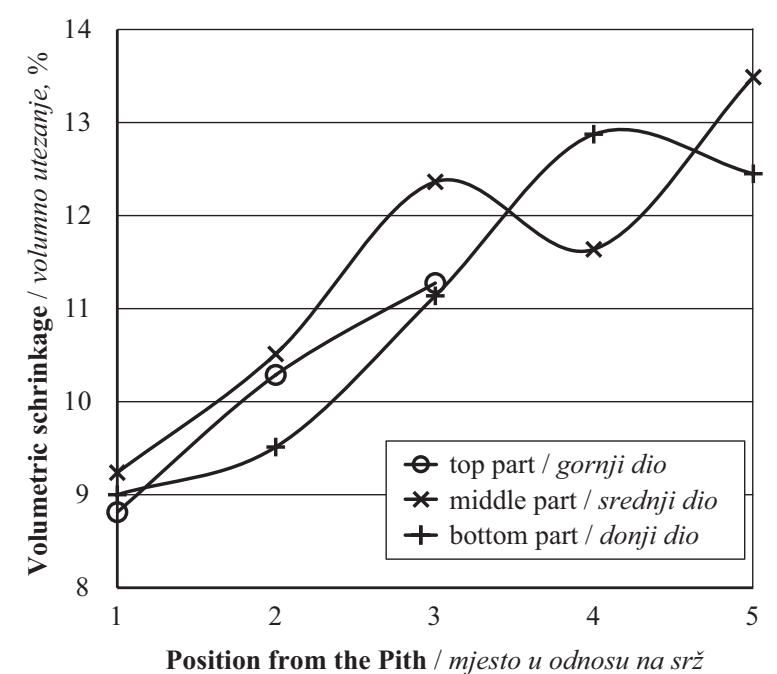

c)

Figure 2 Dependence of tangential (A), radial (B), volumetric shrinkage (C) and density (D) on the trunk horizontal position Slika 2. Ovisnost tangencijalnoga (A), radijalnoga (B) i volumnog utezanja (C) te gustoće (D) o horizontalnom položaju uzorka u stablu

several different stands in this area. The age of the felled trees was in the range of $29-38$ years. The height of the sample trees was in the range of $24-30 \mathrm{~m}$ and the breast-height diameter in the range of $27-36 \mathrm{~cm}$.

Three sections were always taken from the trunks of the felled trees - bottom, middle and top part (Vytisková, 1973; Langum et al, 2009). The sections represent different vertical positions in the trunk. When taking the specimens, the initial orientation in the plants was considered in terms of horizontal position (Sonderegger et al, 2008).

The centre planks were taken from individual sections, and test samples were subsequently prepared in a manner that enabled clear identification of their trunk horizontal position (Gryc and Horáček, 2007; Sonderegger et al, 2008; Langum et al, 2009). Numbers $1,2,3,4,5$ show relative position to the pith, where number 1 means the closest position to the centre of the tree. A closer definition of the method for collecting sections and positions of the test samples in the section is given in Figure 1. Production of the test samples and subsequent wood testing were done in accordance with the national standard (ČSN 49 0101, 1980) in a labora-

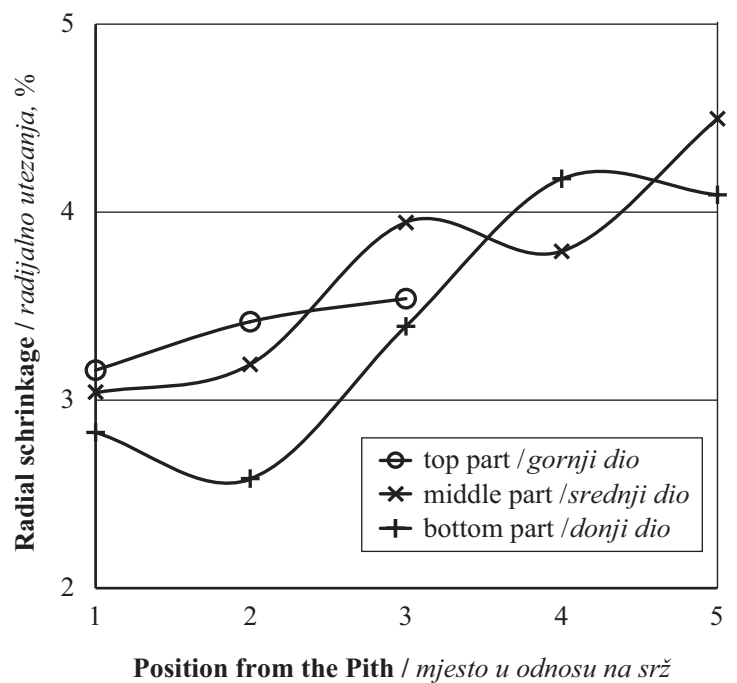

b)

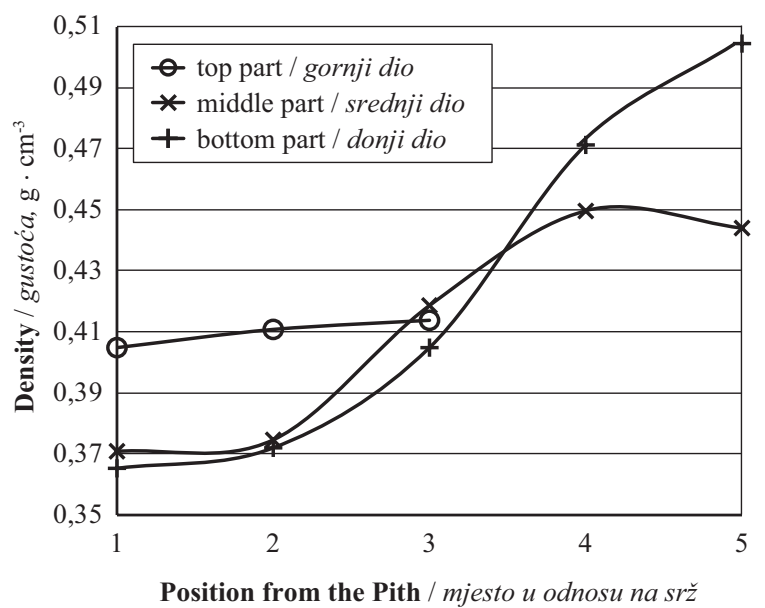

d)

tory with a controlled climate. The test samples used had the shape of squared timber of dimensions $20 \mathrm{~mm}$ x $20 \mathrm{~mm}$ x $25 \pm 5 \mathrm{~mm}$ in tangential, radial and axial direction, respectively.

For each sample, the density was set at $12 \%$ moisture content (ČSN 49 0108, 1993) and subsequently shrinkage in a tangential direction, radial direction and volume shrinkage (ČSN 49 0128, 1989). Total shrinkage, from green state to owen dry condition, was always evaluated in the respective direction.

\section{RESULTS}

\section{REZULTATI}

The average shrinkage value in the tangential direction was $7.1 \%$ and in the radial direction $3.3 \%$. Volume shrinkage was $10.5 \%$. The rest of the descriptive statistics values for shrinkage in the individual anatomical directions and volume shrinkage are given in Table 1.

The progress of tangential shrinkage in relation to the trunk horizontal position shows a rising trend regardless of the vertical position and thus reaches the 
Lukášek, Zeidler, Barcik: Shrinkage of Grand Fir Wood and its Variability within the Stem ...

Table 1 Descriptive statistics for shrinkage of Abies grandis wood

Tablica 1. Deskriptivna statistika vrijednosti utezanja jelova drva

\begin{tabular}{|l|c|c|c|c|c|c|}
\hline $\begin{array}{l}\text { Shrinkage, \% } \\
\text { Utezanje, \% }\end{array}$ & $\begin{array}{c}\text { Valid N } \\
\text { Broj } \\
\text { uzoraka }\end{array}$ & $\begin{array}{c}\text { Mean } \\
\text { Srednja } \\
\text { vrijednost }\end{array}$ & $\begin{array}{c}\text { Minimum } \\
\text { Najmanja } \\
\text { vrijednost }\end{array}$ & $\begin{array}{c}\text { Maximum } \\
\text { Najveća } \\
\text { vrijednost }\end{array}$ & $\begin{array}{c}\text { Standard deviation } \\
\text { Standardna devijacija }\end{array}$ & $\begin{array}{c}\text { Coefficient of variation } \\
\text { Koeficijent varijacije }\end{array}$ \\
\hline $\begin{array}{l}\text { Tangential } \\
\text { tangencijalno }\end{array}$ & 595 & 7.1 & 1.7 & 10.6 & 1.4 & 19.8 \\
\hline $\begin{array}{l}\text { Radial } \\
\text { radijalno }\end{array}$ & 595 & 3.3 & 0.7 & 7.5 & 0.8 & 24.4 \\
\hline $\begin{array}{l}\text { Volumetric } \\
\text { volumno }\end{array}$ & 595 & 10.5 & 3.9 & 16.7 & 1.8 & 17.4 \\
\hline
\end{tabular}

(A)

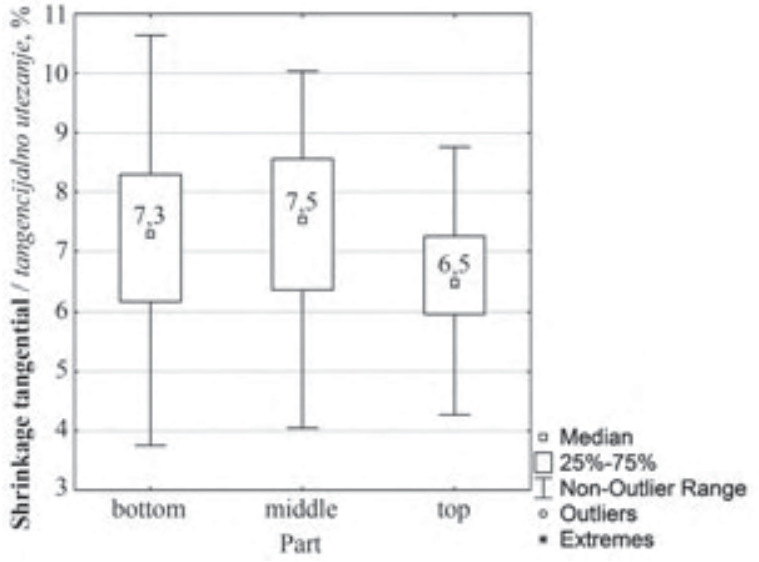

(B)

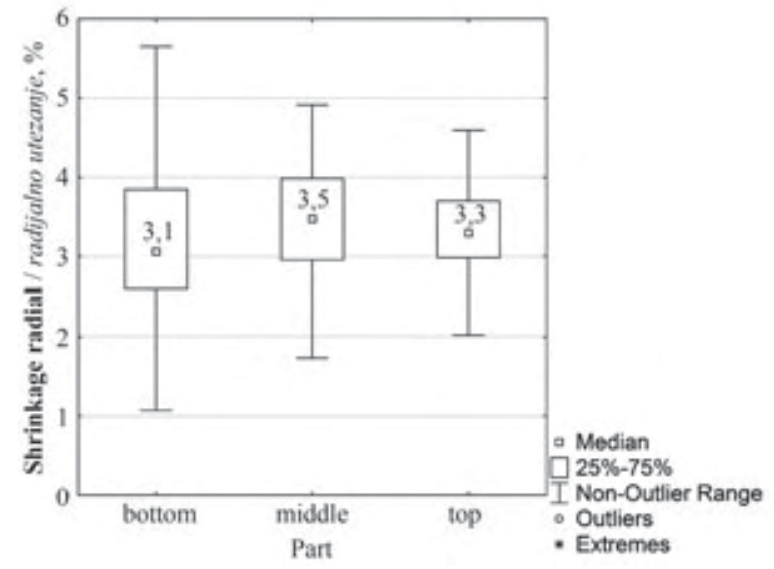

(C)

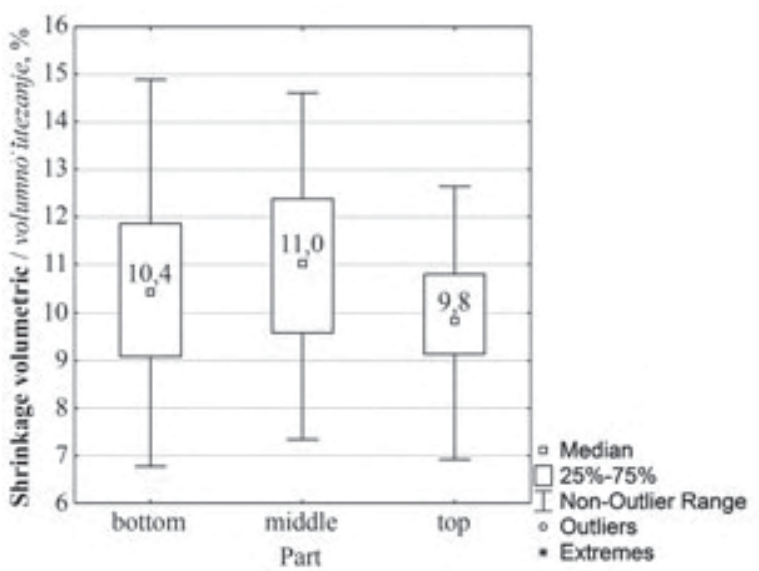

Figure 3 Dependence of tangential (A), radial (B) and volumetric $(\mathrm{C})$ shrinkage on the trunk vertical position Slika 3. Ovisnost tangencijalnoga (A), radijalnoga (B) i volumnog utezanja $(\mathrm{C})$ o vertikalnom položaju uzorka u stablu
(A)

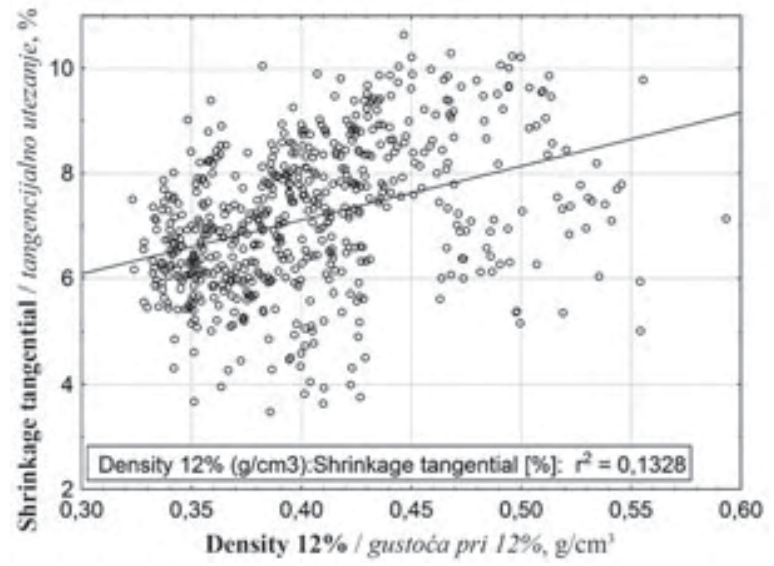

(B)

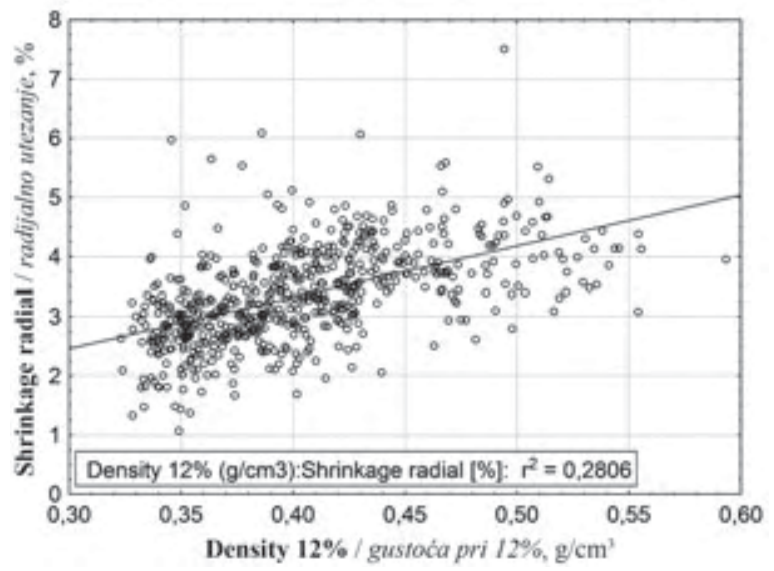

(C)

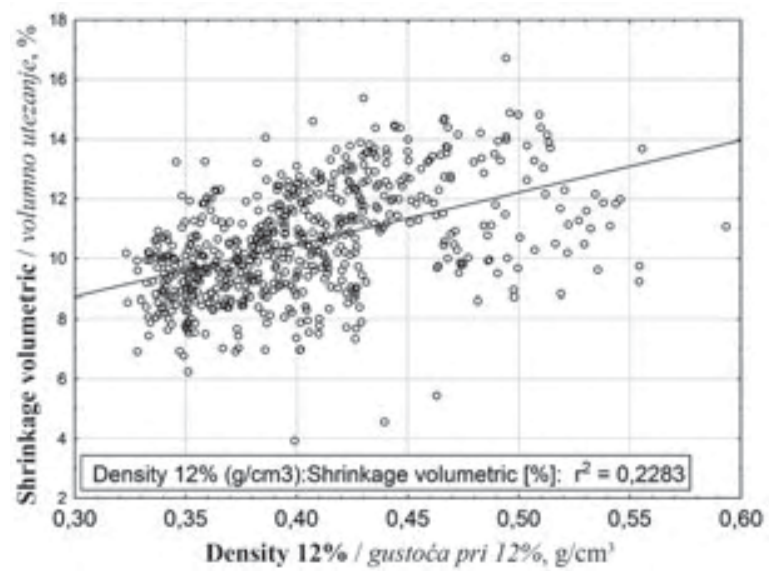

Figure 4 Dependence of tangential (A), radial (B) and volumetric $(\mathrm{C})$ shrinkage on density $(12 \% \mathrm{MC})$

Slika 4. Ovisnost tangencijalnoga (A), radijalnoga (B) i volumnog utezanja (C) o gustoći uzorka (uz $12 \%$ sadržaja vode) 
highest value in the zone furthest from the trunk pith. A similar trend is also observed in radial shrinkage and volumetric shrinkage (Figure 2). Density shows a similar trend to shrinkage, whereby it rises from the pith to the cambium (Figure 2). The most intensive rise in density appears in the bottom section of the trunk, while the mildest is in the top section.

Vertical variability does not have a clear trend in the case of radial shrinkage. The shrinkage values initially rise with height, and then drop towards the top. The lowest radial shrinkage value in the vertical direction is in the bottom section of the trunk. The highest shrinkage value is in the middle section of the trunk. ANOVA (Tukey test, $\alpha=0.05$ ) confirmed the statistically significant difference in the radial shrinkage values between the middle and the bottom sections. Tangential shrinkage is also highest in the middle section of the trunk, the lowest shrinkage values are, however, reached in the top section. The top section shows statistically the lowest tangential shrinkage values. Volumetric shrinkage copies the trend of tangential shrinkage. The lowest shrinkage values are in the top section and the lowest in the middle section of the trunk. The top section shows statistically slower volumetric shrinkage values in comparison with the bottom or middle section. Radial, tangential and volumetric shrinkage has a comparable trend in the vertical direction. Shrinkage initially rises towards the middle section of the trunk and then slightly drops towards the top (Figure 3).

Although the relationship between shrinkage and density has been confirmed as statistically significant, the influence of density on the shrinkage of Grand fir wood is relatively low. The influence of density is most significant on radial shrinkage. However, the determination coefficient is only 0.28 . In the remaining two instances of shrinkage evaluation, the values are even lower, 0.23 for volumetric shrinkage and only 0.13 for tangential shrinkage (Figure 4).

\section{DISCUSSION}

\section{RASPRAVA}

The ascertained shrinkage values for Grand fir from the locality in the Czech Republic correspond to the values attained in the natural habitat. Principally, identical values were obtained for both anatomical directions and volumetric shrinkage (Table 2).

Table 3 shows the comparison of the ascertained values with the quality of grand fir wood from the plan-
Table 2 Comparison of shrinkage values with the values in the natural habitat

Tablica 2. Usporedba dobivenih vrijednosti utezanja s vrijednostima utezanja drva iz prirodnog staništa

\begin{tabular}{|l|c|c|}
\hline & $\begin{array}{c}\text { Simpson, } \\
\text { TenWolde (1999) }\end{array}$ & $\begin{array}{c}\text { Lukášek } \\
\text { et al. }\end{array}$ \\
\hline $\begin{array}{l}\text { Shrinkage tangential, \% } \\
\text { Tangencijalno utezanje, \% }\end{array}$ & 7.5 & 7.1 \\
\hline $\begin{array}{l}\text { Shrinkage radial, \% } \\
\text { Radijalno utezanje, \% }\end{array}$ & 3.4 & 3.3 \\
\hline $\begin{array}{l}\text { Shrinkage volumetric, \% } \\
\text { Volumno utezanje, \% }\end{array}$ & 11.0 & 10.5 \\
\hline
\end{tabular}

Table 3 Comparison of shrinkage values with the values of the rest of the European plantations

Tablica 3. Usporedba dobivenih vrijednosti utezanja s vrijednostima utezanja za drvo s europskih plantaža

\begin{tabular}{|l|c|c|c|}
\hline & $\begin{array}{c}\text { Pelz } \text { et al, } \\
\mathbf{2 0 0 3}\end{array}$ & $\begin{array}{c}\text { Riebel, } \\
\mathbf{2 0 0 7}\end{array}$ & $\begin{array}{c}\text { Lukášek } \\
\text { et al. }\end{array}$ \\
\hline $\begin{array}{l}\text { Shrinkage tangential, \% } \\
\text { Tangencijalno utezanje, \% }\end{array}$ & $7.2-7.5$ & - & 7.1 \\
\hline $\begin{array}{l}\text { Shrinkage radial, \% } \\
\text { Radijalno utezanje, \% }\end{array}$ & $2.5-3.5$ & - & 3.3 \\
\hline $\begin{array}{l}\text { Shrinkage volumetric, \% } \\
\text { Volumno utezanje, \% }\end{array}$ & - & 10.7 & 10.5 \\
\hline
\end{tabular}

tations in the rest of the European countries. It is clear that the shrinkage values of Grand fir in the Czech Republic are similar to those obtained by the authors who evaluated the shrinkage of this introduced wood tree grown in the neighbouring states.

The comparison with our native and commercial softwoods that Grand fir could suitably supplement or even replace is contained in Table 4 . In terms of shrinkage values in the individual anatomical directions and volumetric shrinkage, Grand fir is closest to our domestic Silver fir. Riebel (2007) also arrived at the same conclusion. From just the shrinkage aspect, Grand fir is a suitable replacement.

In terms of shrinkage progress in grand fir trunk in the horizontal direction, the lowest shrinkage value is obtained near the pith. This distribution of shrinkage in the trunk is more or less similar for tangential, and radial as well as volumetric shrinkage. With the exception of the bottom section in the case of radial shrinkage, the vertical position has no influence and shrinkage shows a rising trend from the pith to the bark regardless of the section. The radial distribution of the density copies the shrinkage progress, whereby the lowest

Table 4 Comparison of shrinkage values with the values of the native softwoods grown in the Czech Republic

Tablica 4. Usporedba dobivenih vrijednosti utezanja s vrijednostima utezanja za domaće vrste mekog drva koje rastu u Republici Češkoj

\begin{tabular}{|l|c|c|c|c|}
\hline & $\begin{array}{c}\text { Abies grandis } \\
\text { (Lukášek et al.) }\end{array}$ & Abies alba * & Picea abies * & Pinus silvestris* \\
\hline Shrinkage tangential, \% / Tangencijalno utezanje, \% & 7.1 & $7.2-7.6$ & $7.8-8.0$ & $7.5-8.7$ \\
\hline Shrinkage radial, \% / Radijalno utezanje, \% & 3.3 & $2.9-3.8$ & $3.5-3.7$ & $3.3-4.5$ \\
\hline Shrinkage volumetric, \% / Volumno utezanje, \% & 10.5 & $10.2-11.5$ & $11.6-12.0$ & $11.2-12.4$ \\
\hline Density 12\%, $\mathrm{kg} \cdot \mathrm{m}^{-3}$ / Gustoća pri 12\%, $\mathrm{kg} \cdot \mathrm{m}^{-3}$ & 405 & 450 & 470 & 510 \\
\hline
\end{tabular}

* Wagenführ 2000 
shrinkage value is near the pith, regardless of the vertical position, and has a rising trend toward the bark. The rising shrinkage values from the pith toward the bark are confirmed by Herritsch (2007), Wang et al. (2008). This phenomenon is attributed mainly to the presence of juvenile wood in the central zone of the trunk, and to the different microfibril angle of the cell wall of the juvenile wood in comparison with the angle of mature wood (Panshin and De Zeeuw, 1980; Larson et al, 2001; Perstoper et al, 2001; Yamashita et al, 2009; Leonardon et al, 2010).

Concerning the influence of the vertical position in the trunk on shrinkage distribution, a marked trend is not discernible in the case of Grand fir. Mild rise in the shrinkage from the bottom to the tree-top is in the middle section of the trunk replaced by a mild drop. With the exception of radial shrinkage, statistically the lowest value is obtained in the upper section of the trunk. The ambiguous trend in the vertical distribution of the dimensional changes of wood in the trunk in relation to the change of moisture content is confirmed by Gryc et al. (2007) and Wang et al. (2008). Just like in the case of radial variability, the vertical progress of the features is influenced by the portion of juvenile wood in individual trunk sections and its structural difference from mature wood (Zobel and Van Buitenen, 1989). A relatively surprising factor is the vertical progress of density, whereby its value rises with rising height and is the highest at the top part. Higher values of density in the upper section of the trunk are given by Dumail and Castera (1997). A different statistical density value is only in the middle section of the trunk. The differences in the density values in the bottom section and the top section cannot, however, be statistically proven (ANOVA, Tukey test, $\alpha=0.05$ ) and it is not possible to talk about any significant trend in dependence of density on vertical position. The small influence of tree height on density is confirmed by Herritsch (2007) for Pinus radiata.

Shrinkage of both juvenile and mature wood is closely correlated to the wood density (Panshin and De Zeeuw 1980; Larson et al. 2001). Positive correlation of density and shrinkage was found by Bengtsson (2001), Perstoper et al. (2001) and Yamashita et al. (2009). The influence of density on the shrinkage of Grand fir wood is relatively low and is the most significant in radial shrinkage (Figure 4). The low value of the determination coefficient for the dependence of shrinkage on density is given by Kärki (2001). Niemz and Sonderegger (2003) state the determination coefficient for tangential swelling in relation to the density of wood at an average value of 0.39 for selected industrially processed woods. Also Kord et al. (2010) state a determination coefficient of 0.39 for the dependence of tangential shrinkage on wood density.

\section{CONCLUSION}

\section{ZAKLJUČAK}

The conclusions of this study targeted at the assessment of the shrinkage of Grand fir wood and its variability within the stem from the selected area in the Czech Republic are as follows:

- The shrinkage values for Grand fir in the climatic conditions of the Czech Republic correspond to the values obtained in the natural habitat.

- The shrinkage values are identical to those obtained in other European countries.

- Based on the shrinkage, Grand fir wood from domestic trees is the closest to the Silver fir wood.

- The influence of radial position on shrinkage variability was clearly proved, whereby the lowest values of all the assessed shrinkages are obtained in the centre of the trunk and rise towards its outer perimeter.

- The vertical position does not clearly influence the size of the shrinkage, whereby it was not possible to monitor the significant trend in the distribution of the shrinkage over the height of the trunk.

- The positive dependence of all the evaluated types of shrinkage on density was proven. The usage of the density value as an indicator of the degree of shrinkage is, however, disputable because the ascertained determination coefficients are relatively low.

- In terms of the overall concept of research focused on the evaluation of Grand fir wood quality, consequences for its processing and possibilities for its application, it can be concluded that Grand fir is a potential substitute for the indigenous Silver fir. However, this is a partial conclusion only based on comparison of shrinkage. Due to the substantially lower density in comparison with the domestic fir, additional tests shall be done, mainly of mechanical characteristics, and a complex comparison of these species will be performed.

\section{Acknowledgements - Zahvala}

This project was supported by the Internal Grant Agency of the Faculty of Forestry and Wood Sciences of the Czech University of Life Sciences in Prague. I also thank the Forest Enterprise in Kostelec nad Cernymi lesy for the material provided.

\section{REFERENCES}

\section{LITERATURA}

1. Alden, H. A., 1997: Softwoods of North America. Gen. Tech. Rep. FPL-GTR-102. Madison, WI: U.S. Department of Agriculture, Forest Service, Forest Products Laboratory.

2. Bengtsson, CH., 2001:Variation of moisture induced movements in Norway spruce (Picea abies) Ann. For. Sci. 58(5): 568-581 http://dx.doi.org/10.1051/forest:2001146.

3. Beran, F., 2006: Některé poznatky z hodnocení mezinárodního provenienčního pokusu s jedlí obrovskou Abies grandis /Douglas/ Lindl. Douglaska a jedle obrovská - opomíjení giganti, Sborník recenzovaných referátů. Kostelec nad Černými lesy. Česká zemědělská univerzita v Praze, Fakulta lesnická a enviromentální, Katedra pěstování lesů a Školní lesní podnik v Kostelci nad Černými lesy. 17-28.

4. Beran, F.; Šindeláŕ, J., 1996: Perspektivy vybraných cizokrajných dřevin v lesním hospodářství České republiky. Lesnictví-Forestry. 42(8): 337-335. 
5. Bosshard, H., 1974: Holzkunde: band 2 Zur Biologie, Physik und Chemie des Holzes. Basel und Stuttgart: Birhäuser Verlag.

6. Dumail, J.F.; Castera, P., 1997: Transverse Shrinkage in maritime pine juvenile wood. Wood Science and Technology. 31: 25-264 http://dx.doi.org/10.1007/BF00702613.

7. Foiles, M. W.; Graham, R.T.; Olson, D.F., 1991: Grand Fir. Silvics of North America: Conifers. United States Forest Service. 52-68.

8. Gryc, V.; Horáček, P. 2007: The Variability of Spruce (Picea abies $/ \mathrm{L} . /$ Karst.) Wood density with Present Reaction Wood. Journal of Forest Sciences. 53(3): 129-137.

9. Gryc, V.; Vavrčík, H.; Horáček, P., 2007: Variability in swelling of spruce (Picea abies [L.] Karst.) wood with the presence of compression wood. Journal of forest science, 53(6): 243-252.

10. Hapla, F., 2006: Use- and Wood Product- orientated Investigation on Abies grandis of different growth dynamics: An experimental Design. Kurjatko, S.; Kúdela, J.; Lagaňa, R. Wood Structure and Properties '06. Zvolen. Arbora Publishers. 51-52.

11. Hapla, F.; Wellhausen, K., 2003: Verwendungsrelevante Holzeigenschaften und Verwendungsbereiche der Großen Küstentanne - Abies grandis (Douglas) Lindley - mit Aufkommensanalyse im Staatswald Niedersachsen. Institut für Holzbiologie und Holztechnologie, Universität Göttingen.

12. Herritsch, A., 2007: Investigations on Wood Stability and Related Properties of Radiata Pine. University of Canterbury. Disertation thesis.

13. Hof, CH.; Kielmann, B., C.; Hapla, F., 2008: Verwendungsorientierte Untersuchungen am Schnittholz der Abies grandis. Holztechnologie. 49(6): 7-11.

14. Jozsa, L., A.; Middleton, G. R., 1994: A discussion of wood quality attributes and their practical implications. Vancouver. Forintek Canada Corp.

15. Kärki, T., 2001: Variation of wood density and shrinkage in European aspen (Populus tremula). Holz als Roh- und Werkstoff. 59: 79-84 http://dx.doi.org/10.1007/s001070050479.

16. Klinka, K., 2007: Die Grosse Küstentanne (Abies grandis Lindl.) in Kanada und in den USA. Forst und Holz. 62(7): 10-13.

17. König, A., 1995: Geographic Variation of Abies grandis - Provenances Grown in Northwestern Germany. Silvae Genetica. 44(5-6): 248-255.

18. Kord, B.; Kialashaki, A.; Kord, B., 2010: The within-tree variation in wood density and Shrinkage, and their relationship in Populus euramericana. Turk J Agric For. 34: 121-126.

19. Langum, CH., E.; Yadama, V.; Lowell, E. C., 2009: Physical and Mechanical Properties of Young-Growth Douglas-Fir and Western Hemlock from Western Washington. Forest Products Journal. 59(11/12): 37-47.

20. Larson, P. R.; Kretschmann, D. E.; Clark, Alexander III; Isebrands, J.G., 2001: Formation and properties of juvenile wood in southern pines: a synopsis. Gen. Tech. Rep. FPL-GTR-129. Madison, WI: U.S. Department of Agriculture, Forest Service, Forest Products Laboratory.

21. Leonardon, M.; Altaner, C. M.; Vihermaa, L.; Jarvis, M. C., 2010. Wood schrinkage: influence of anatomy, cell wall architecture, chemical composition and cambial age. Eur. J. Wood Prod., 68: 87-94 http://dx.doi.org/10.1007/s00107-009-0355-8.

22. Mitze, H., 2010: Ein unterschätzer Nordamerikaner: Küstentanne. Forstwirtschaft: Land \& Forst., 26: 66-67.

23. Niemz, P., 1993: Physik des Holzes und der Holzwerkstoffe. Weinbrenner: DRW- Verlag.
24. Niemz, P.; Sonderegger, W., 2003: Untersuchungen zur Korrelation ausgewählter Holzeigenschaften untereinander unt mit der Rohdichte unter Verwendung von 103 Holzarten. Schweizerische Zeitschrift für Forstwesen, 12: 489-493 http://dx.doi.org/10.3188/szf.2003.0489.

25. Panshin, A. J.; De Zeeuw, C., 1980: Textbook of wood technology. 4th edition, New York: Mc-Graw-Hill.

26. Pelz, S.; Mehlin, I.; Becker, G.; Bücking, M., 2003: Eigenschaften und Verwendungsoptionen von Abies grandis und Abies procera: Zusammenfassende Ergebnisse einer Literaturstudie. Forst und Holz, 58(10): 290-296.

27. Perstorper, M.; Johansson, M.; Kliger, R.; Johansson, G., 2001: Distortion of Norway spruce timber: Part 1. Variation of relevant wood properties. Holz als Roh- und Werkstoff, 59: 94-103 http://dx.doi.org/10.1007/s001070050481.

28. Podrázský, V.; Remeš, J., 2008: Půdotvorná role významných introdukovaných jehličnanů - douglasky tisolisté, jedle obrovské a borovice vejmutovky. Zprávy lesnického výzkumu, 53(1): 27-33.

29. Podrázský, V.; Remeš, J., 2009: Soil-forming effect of Grand fir (Abies grandis /Dougl. ex D.Don/Lindl.). Journal of forest science, 55(12): 533-539.

30. Požgaj, A.; Chovanec, D.; Kurjatko, S.; Babiak, M., 1997: Struktúra a vlastnosti dreva. Bratislava: Príroda.

31. Rau, H. M.; König, A.; Ruetz, W.; Rumpf, H.; Schönfelder, E., 2008: Ergebnisse des westdeutschen IUFRO Küstentannen- Provenienzversuches im Alter 27: Beiträge aus der Nordwestdeutschen Forstlichen Versuchsanstalt, Band 4. Göttingen: Universitätsverlag Göttingen.

32. Riebel, H., 2007: Die Grosse Küstentanne [Abies grandis (Dougl. ex. D.Don.) Lindl.]:Holzeigenschaften und Holzverwendung. Forst und Holz, 62(6): 21-26.

33. Simpson, W.; TenWolde, A., 1999: Physical properties and moisture relations of wood. In: Wood handbook Wood as an engineering material. Madison, US Department of Agriculture, Forest Service, pp. 3.1-3.24.

34. Šindelář, J.; Beran, F.; Frýdl, J.; Novotný, P., 2006: K možnostem lesnického využití některých cizokrajných druhů rodu Abies v ČR na základě hodnocení jejich růstu na lokalitě Jíloviště - Cukrák ve věku 30 let. Zprávy lesnického výzkumu, 51(4): 235-242.

35. Sonderegger, W.; Mandallaz, D.; Niemz, P., 2008: An investigation of the influence of selected factors on the properties of spruce wood. Wood Science and Technology, 42: 281-297 http://dx.doi.org/10.1007/s00226-007-0173-2.

36. Tauchman, P.; Hart, V.; Remeš, J., 2010: Srovnání produkce porostu douglasky tisolisté (Pseudotsuga menziesii / Mirbel/ Franco) s porostem smrku ztepilého (Picea abies L. Karst.) a stanovištně původním smíšeným porostem středního věku na území ŠLP v Kostelci nad Černými lesy. Zprávy lesnického výzkumu, 55(3): 187-194.

37. Vos, H.; Kharazipour, A., 2010: Eigenschaften von leichten, industriell hergestellten Spanplatten aus Abies grandis (Küstentanne). Forst und Holz, 65(1): 26-30.

38. Vytisková, M., 1973: Kvalita dřeva vejmutovky (Pinus strobus L.). Praha: SNTL.

39. Wagenführ, R., 2000: Holzatlas. Leipzig: Fachbuchverlag.

40. Wang, E.; Chen, T; Pang, S.; Karalus, A., 2008: Variation in anisotropic schrinkage of plantation-grown Pinus radiata wood. Moderas. Cienoia y techologia, 10(3): 243-249.

41. Yamashita, K.; Hirakawa, Y.; Nakatani, H.; Ikeda, M., 2009: Tangential and radial shrinkage variation within trees in sugi (Cryptomeria japonica) cultivars. J Wood Sci, 55: 161-168 http://dx.doi.org/10.1007/s10086-008-1012-2. 
42. Ying, L.; Kretschman, D.E.; Bendtsen, B.A., 1994: Longitunidal schrinkage in fast-grown lobolly pine plantation wood. Forest product Journal, 44(1): 58-62.

43. Zobel, B.J.; Van Buitenen, J.P., 1989: Wood variation, its causes and control. Berlin: Springer-Verlag http://dx.doi.org/10.1007/978-3-642-74069-5.

44. *** ČSN 490101 (1980): Drevo - Všeobecné požiadavky na fyzikálne a mechanické skúšky.

45. *** ČSN 490108 (1993): Drevo - Zist'ovanie hustoty.

46. *** ČSN 490128 (1989): Skúšky vlastností rastlého dreva - Metóda zist'ovania zosýchavosti.

47. *** MZE 2010: Report on the forests state and forest management of the Czech Republic. Prague: Ministry of Agriculture.

\section{Corresponding address:}

Asisst. Prof. ALEŠ ZEIDLER, Ph.D.

Faculty of Forestry and Wood Sciences,

Czech University of Life Sciences Prague

Kamýcká 129

Praha 6 - Suchdol 165 00, CZECH REPUBLIC

e-mail: zeidler@fld.czu.cz 